\title{
Esențialitatea diacroniei
}

\author{
Francisc Gafton* \\ Facultatea de Litere, Universitatea „Alexandru Ioan Cuza”, Bd. Carol I 11, 700506 Iași, România
}

\section{Despre articol}

Istoric:

Primit 21 decembrie 2014

Publicat 13 ianuarie 2015

Cuvinte-cheie:

organism

evoluţie

diacronie

sincronie

\begin{abstract}
Rezumat
Entitățile naturale primare-plantele și animalele-sau derivate-societatea, limba şi cultura - apar prin anevoios travaliu diacronic, au a răspunde unor nevoi dezvoltate diacronic, există și funcționează diacronic. Cu toate acestea, prin instrumentele sale, omul poate doar percepe și surprinde fragmentul, fixîndu-l pentru o clipă prelungită, motiv obiectiv pentru care el segmentează realitatea spațio-temporală în conformitate cu propriile proporții și capacități. Aceasta însă nu se poate supune segregării nefirești a unuia dintre produsele și elementele ei, pe deplin neputînd fi înțeleasă decît așa cum există ea, ca întreg. După completarea parcursului sincronic, cea care poate oferi cuprinderea și înțelegerea întregului care devine este calea metodei diacronice.
\end{abstract}

„Teoria selecției naturale trebuie acceptată nu pur și simplu ca o lege biologică, ci ca un principiu al lumii naturale, care îşi găsește aplicarea adecvată in toate științele vieții și ale minții.” (James Mark Baldwin)

\section{Introducere}

În mod firesc, generațiile de oameni percep doar prezentul pe care-l trăiesc, cel al supraviețuirii, cu toate că natura lor profundă și reală este diacronică. Întocmai precum fiecare nou ciclu al inimii este necesar vieții, precum fiecare pas se orînduiește în chipul și în continuarea precedentului și precum la fiecare generație, aceeaşi genă transmite aceeași informație și determină acelaşi proces sau capacitate, tot astfel existența deplină și reală nu este posibilă fără continua înțelegere și (re)amintire a dimensiunii diacronice, a nehybricei realități că fiecare individ este o celulă a cărei proprie viață nu are sens și nici existență reală în afara vieții organismului; că orice îşi are punctul de plecare în trecut, că înțelegerea a orice poate apărea doar parcurgînd acel drum evolutiv. De aceea, prezentul deplin și potențialul unui viitor deplin se află în prezentul care și-a încorporat trecutul.

\section{Dinamica structural-funcțională}

Entităţile precum celula vegetală, individul animal sau societatea sînt organisme care, dincolo de gradele lor de complexitate, împărtășesc seturi comune de trăsături structural-funcționale și comportamentale. Constituția unei celule sau a oricărui alt fel de vietate normală este în chipul entității care o generează și produs al unor procese anterioare; sub aspect structural, entitățile sînt rezultante ale unor stări și procese preexistente lor. Funcționarea respectivei celule se petrece în concordanță cu capacitățile ei structurale moștenite și cu nevoile ei-relativ la solicitările ansamblului bio-spaţio-temporal din care face parte-; sub aspect funcțional, entitatea este rezultanta exercițiului acelor structuri, determinat de interacțiunea cu mediul, adică ajustat de nevoile entității în relație cu cerințele mediului.

*Adresă de corespondență: algafton@gmail.com. 
Acomodările organismului se produc în limitele îngăduite de echipamentul structural, prin convertirea/încărcarea structurilor existente la/cu noi funcțiuni. Eventualele modificări structurale pot fi generate de exerciţiul îndelungat și unidirecționat al structurilor, orientat de constanta presiune a nevoilor și a mediului. Adaptarea este răspunsul pe care, prin intermediul structurii, îl dă organismul aflat sub imperiul nevoii interne și al cerinței mediului.

Sistemele biologice-dar nu exclusiv acestea-își moștenesc structura, însă nu ca pe un dat imuabil, ci ca pe un cadru capabil de a se adapta la eventuale nevoi interne și viitoare cerințe externe. La rîndul lor, funcțiunile se moștenesc doar ca virtualități, ele fiind determinate de posibilitățile oferite de structură și de solicitările concrete ale realității.

Structurile și funcțiunile nu au un curs rectiliniu-uniform. O schemă simplificată dar realistă ar arăta că într-un mediu cu solicitări echilibrate, structura unei generații provine din structura consolidată (prin colaborarea și lupta elementelor) a generațiilor anterioare, funcționarea ei fiind la fel de asemănătoare cu cea a ascendenței. În condițiile unui mediu solicitant sau care însumează acumulări ce depășesc capacităţile mediului însuși de a-și păstra constantele moștenite (mediul nefiind altceva decît rezultanta coexistenței a numeroase tipuri de sisteme, la nivele diferite fiecare organism fiind mediu şi organism), structura unei generaţii are aceeaşi bază precum în cazul de mai sus, însă începe să fie solicitată în direcția unor ajustări induse de acomodarea la solicitările intense și/sau acumulate în timp, și care au depășit pragurile de echilibru și rezistență ale structurilor anterioare. Unele acumulări de factori și modificări calitative ale mediului au drept rezultat solicitări funcționale ce nu pot fi satisfăcute decît prin adaptări structurale. În cazul în care presiunile dinspre cerințele mediului depășesc capacitățile de răspuns ale structurilor, nevoile interne depăşesc limitele acestora de a se încărca sau converti (parțial), iar soluția cea mai eficientă poate deveni aceea a modificării acestora. Excedate, structurile îşi transmit particularitățile încă utile, noile structuri aducînd cu sine noi soluții și răspunsuri funcționale, conform solicitărilor ce-au inițiat și determinat schimbarea. După o perioadă în care solicitările funcționale induc aceleași cerințe funcționale, noile generații vor ajunge să moștenească noile date structurale, noile valențe funcționale, la noul nivel un nou echilibru instaurîndu-se.

Între structură și funcție, așadar, există un oarecare decalaj (spațio-)temporal. Cea dintîi constituie un suport material și o formă decurgînd dintr-o structură anterioară. Servind realizării schimbului de substanță și de energie cu mediul (inclusiv cu alte sisteme) în vederea supraviețuirii, structurile unui sistem disipativ trebuie să fie capabile să-și prelucreze materialul care le constituie, în cele din urmă, adică, să fie adaptabile la modalitățile de existență și de funcționare ale mediului. Acomodarea unei structuri la cerințele mediului este modulată și conformizată de exercițiul funcțiilor sale, însă se petrece în limitele capacităţilor potențialului intern al structurii. Cea de-a doua este o activitate prin care se exercită funcții subsecvente-corespunzînd acelei structuri-care împlinesc nevoi interne, și consecvente-permise de acea structură—, răspunzînd solicitărilor mediului și interacțiunii cu acesta.

Date fiind caracteristicile structural-funcționale ale organismelor, precum și modalitățile în care acestea se racordează la sistemele sub- şi supraordonate, ratele evoluțiilor petrecute la diferite nivele sînt diferenţiate, structurile fiind mai stabile decît funcțiunile, elementele primare, de bază și identitare fiind mai stabile decît cele derivate. De aceea percepțiile și impresiile se schimbă mai lent decît modul de a le traduce prin limbă în gîndire, iar formele limbii se schimbă mai lent decît conținuturile gîndirii. În plan lingvistic, deși oscilații și torsiuni se pot înregistra în toate compartimentele-acestea distribuindu-se diferit în funcție de epoci și de dinamica normei lingvistice-, structura, elementul de stabilitate și dătător de identitate sînt reprezentate de nivelele fonetic și morfologic, în vreme ce dinamica sintactică și mai ales labilitatea semantică constituie componenta variabilă și dinamică a limbii. Dincolo de neajunsurile acestor decalaje, 
rolul lor este de a asigura continuitatea și identitatea sistemică, așa cum în timpul mersului, corpul nu părăsește pămîntul nici o clipă și pe deplin, deși își schimbă poziția.

Parcurgînd generațiile, cea dintîi devine o construcție—parțial dată, continuu ajustabilă — ce oferă posibilități de interacțiune cu mediul, adică de exercitare a funcțiilor ${ }^{1}$. Constituite pe principii vechi, actualizate de nevoi și solicitări mai puțin vechi, construcțiile sînt apte să exercite funcțiuni ce corespund unui complex preexistent, dar și să exercite funcțiuni ce răspund unui set de cerințe contemporane.

Din cele de mai sus rezultă și că sub aspect structural și funcțional entitățile vii, aparținătoare unei comunități existînd într-un mediu și într-o epocă, sînt rezultantele unor procese organice și interacționale desfăşurate istoric. Aceste procese privesc integrarea în mediu și adaptarea la acesta, suplețea trăsăturilor structural-funcționale permițînd adaptarea la mediu și chiar schimbarea acestuia. Întrucît decurg dintr-un șir de adaptări ce răspund unor factori concreți, care determină cerințe externe ce impun nevoi interne, trăsăturile sînt dinamice, variabile și evolutive.

Pe fondul unui mediu cu o dinamică ce impune evoluția adaptativă, capacitatea de stocare a informației este limitată, necesitatea cerînd acumularea unei cantități optime, direct proporționale cu complexitatea organizațională și funcțională. În plus, diferențierea și specializarea componentelor sistemului crește gradul de interdependență a structurilor, de complexitate a organizării și integritatea organismului, fapt ce sporește nevoile interne și are urmări la nivelul răspunsului sistemului la cerințele externe. Acest dat al dinamicii interne, în relație cu impunerile mediului, este în măsură să solicite stabilitatea organismului, deoarece tendința către echilibru dinamicprin care organismul se adaptează la mediu—și autoreglarea-prin care el încearcă să se echilibreze intern, dar ca urmare a interacțiunii cu mediul—generează valențe entropice. Un nivel de echilibru nu se păstrează decît relativ oscilant, deoarece solicitările dinspre mediu pot depăşi anumite praguri, cărora nu li se poate răspunde decît prin modificări structural-funcționale. Mai mult, eforturilor de răspuns direct ale organismului li se pot adăuga nevoile interne de calibrare sau chiar de progres (anticipator al cerințelor mediului sau ameliorant al propriilor structuri și funcțiuni). Rezolvarea acestor probleme implică noi eforturi de reechilibrare, lucru ce se poate obține pe o altă treaptă a evoluției, vremelnic, deoarece noi provocări vor exersa procesul evolutiv al materiei.

Deși identitatea organismelor pare a se afla în continuă devenire, în condițiile unui mediu dinamic și solicitant, identitatea acestora manifestă mai degrabă tendințe de prezervare și capacități de acomodare. Ceea ce caracterizează organismele este continuitatea organică și identitatea cu specia, materialul constitutiv, principiile de ordonare și de funcționare rămînînd neschimbate, indiferent de constelațiile generate și de solicitările cărora acestea le sînt supuse.

\section{Fundamentalitatea evoluției}

Privirea prospectivă, dinspre un punct oarecare, dezvăluie faptul că mișcările adaptative răspund anumitor nevoi interne de recalibrare și unor cerințe externe de acomodare, adaptarea nefiind o soluție ce vizează durabilitatea sau evoluția direcționată, ci modalitatea cea mai eficientă de potrivire concretă, oportună și eficientă la impunerile realității, spre păstrarea stării de existență. Lucrurile se petrec astfel deoarece constructele naturii nu se produc în conformitate cu vreun plan sau în vederea vreunui scop (de nici un fel, cu atît mai puțin uman, edificat în virtutea unei ideologii, a unei morale etc.). Perfecțiunea unui organ, armonia părților, conjuncția lor echilibrată, funcționarea eficientă nu sînt scopuri în sine, ci rezultate efemere ce împlinesc nevoi presante servind adaptării optime a organismului la cerințele realității, vizînd

\footnotetext{
${ }^{1}$ Un organism nu este o entitate izolată, ci este parte a mediului în care există, interacțiunea fiind vitală, nu doar ca necesitate de a supraviețui, ci și ca o condiție a existenței.
} 
asigurarea supraviețuirii eficiente, atît în raport cu sine, cît și cu mediul; pentru sine, dar ca element integrat al mediului.

Configuraţia organismului (ca rezultantă a relațiilor dintre structuri și funcțiuni) și relația de tip provocare-răspuns a acestuia cu mediul (ca rezultantă a dinamicii dintre nevoile interne și cerințele externe) nu sînt doar stări ce au a suferi schimbarea, ci și puncte de plecare ale schimbării. Astfel, nivelul dotării și al adaptabilității, ambele în raport cu mediul, intră în relație cu caracterul imperios al constrîngerilor interne și mai ales externe, forța cu care se manifestă solicitările, reacția posibilităților și capacităților organismului la această conjuncție dînd tăria răspunsului. Răspunsul reflectă nivelul dotării și al adaptabilității, capabilitatea organismului, și concretizează investiția energetică, gestionînd ritmul de satisfacere a nevoii, acuratețea restructurării, corelarea cu alte nevoi. Amploarea procesului este dată de numărul, trăsăturile și nevoile elementelor intrate în joc, de complexitatea structurală și/sau funcțională, la nivel structuralfuncțional procesul fiind de așa natură încît indiferent de complexul anatomo-fiziologic în sine el urmează căi ce vizează rezultatele interacțiunilor diferitelor părți, în raport cu cerințele solicitării.

$\mathrm{Cu}$ alte cuvinte, nici procesul nu „se preocupă” de acuratețea constitutivă și funcțională a unei părți sau a unui organ, ci vizează eficiența funcțională a organismului; corecta conjuncție a părților ansamblului și corelarea eficientă a funcțiilor constituie doar consecințele mizei centrale: adaptarea organismului la mediu spre a-şi optimiza existența.

Întregul joc poate părea aleator, dar este aproape sigur că el se petrece în conformitate cu anumite principii sau legi. În acest chip, materia biologică și socială intră în relație și își armonizează atributele și exerciţiul, creînd o structură funcțională.

Privind retrospectiv, către un punct oarecare, se pot înțelege modalitățile în care, prin acțiunile ei, ființa umană și-a putut ameliora activitatea integrativă și existențială din cadrul unui organism mai mare. Precum societatea din care face parte, individul este o entitate continuă—desigur, la nivelul existenței sale-, iar prin relația intra- și intergenerațională, este o etapă a unui proces neîntrerupt. El este congruent cu semenii contemporani, dar în sensul entității alternative din cadrul aceleiași realități-și aceasta supusă jocului evoluției, și ea identică în esență, neidentică prin accident, aparență și devenire. Prin jocul dintre stabilitate și variabilitate, fiecare este identic cu sine sub anumite aspecte, dar are capacități adaptative și evolutive prin care își pierde identitatea la un nivel spre a o ameliora la un altul.

Existența unei componente dotate cu trăsături particulare structural-funcționale are sens doar în măsura în care particularitățile ei o fac aptă să interacționeze cu alte asemenea componente, formînd o entitate structural-funcțională superioară. Superioritatea entităţii rezultate decurge din calitatea structural-funcțională a componentelor, precum şi din calitatea rezultatului interacțiunii acestora. Celulele (oricărui nivel) pot deveni elemente componente, comportîndu-se ca atare, interacționînd și formînd structuri complexe și variate. În cadrul interacțiunii dintre structurile celulare se produce, deopotrivă, acomodarea componentelor; aici, însă, componentul aparține mai multor nivele sau chiar structuri complexe, aşadar ajustarea este mai complexă, nefiind doar o acomodare la componentele de același rang, ori la cerințele rangului, ci o adaptare la un complex de cerințe provenit din activitatea tuturor nivelelor.

Oricît de izolat s-ar concepe un individ și oricîte tendințe de autoconservare ar prezenta acesta-firești pînă la limita obținerii modalităţilor optime de existență la cel mai înalt nivel calitativ, spre asigurarea urmașilor de cea mai bună calitate-, împlinirea reală a existenței sale derivă din înțelegerea faptului că viața sa este o etapă din existența aminoacizilor care îl constituie vremelnic. În adevăr, aceasta este singura formă de nemurire, negarantată, dar realizabilă.

Un principiu al lumii vii-mai puțin în cazul unui defect genetic-este că asigurarea de către individ a condițiilor supraviețuirii individuale îl conduce pe acesta la a fi participant la viața 
comunității sau a speciei ${ }^{2}$. Nu este un calcul, ci un dat natural.

Din acest motiv, împlinirea existenței personale devine reală atunci cînd tradiția moștenită este valorificată la cel mai înalt nivel, apoi-după îmbogăţirea ei cu cele mai de seamă calităţi generate de propria existență-este transmisă urmașilor în cele mai adecvate forme și modalități asimilabile, echipată cu cele mai adaptate potențialități de continuare a existenței. Existînd prin lanț-poate mai mult decît acesta prin zalele sale-, fiecare verigă trebuie să potențeze lanțul pe care îl compune (la care nu doar participă) și trebuie să-i sporească atributele potențiale.

A nu ține seamă de complexitatea structural-funcțională a organismului din care o entitate face parte, și de relaţiile legiferate în cadrul întregului complex, poate tolera oarecare dezvoltare și calm, ambele aparente căci ele nu ar fi decît consecința activității funcțiilor de autoreglare ale organismului. Acestea nu pot rămîne active decît pe baza acumulărilor precedente și pînă în punctul în care dinamica realității o permite, în condițiile neschimbării cerințelor și solicitărilor. Ignorarea organicității și istoricității proceselor este o cale ce duce la evenimente catastroficefapt de asemenea dotat cu caracter legic.

Acest imperativ poate fi estompat de faptul că, datorită variabilităţii naturale şi a adaptării la realitate, punctele de plecare ale generațiilor nu sînt mereu identice, începutul însuși fiind supus dinamicii, la intervale mai mari sau mai mici acumulările sedimentîndu-se și înscriindu-se în gene. Dintre toate, probabil că această trăsătură a mersului evoluției este cea mai specioasă, deoarece așterne indivizilor și generațiilor capcana de a se raporta doar la realităţile contemporane lor.

\section{Sincronia ca instrument al diacroniei}

Lumea poate fi privită și analizată, gîndită, interpretată și înțeleasă din două perspective: una pune detaliul sau partea sub microscop, plasînd cercetătorul pe poziția iluzorie a observatorului extern și obiectiv; cealaltă contemplă organismul și lumea, aflate în devenire, socotind pe cercetător ca parte congeneră a devenirii urmărite. Datorită naturii obiectului, a scopului vizat, a căii practicate și a poziției cercetătorului, cele două perspective se deosebesc fundamental.

Aplicînd metoda sincronică, cercetătorul secționează organismele și procesele, le înșiră pe masa de lucru privindu-le și cercetîndu-le aidoma unui receptor și analizator, urmărind detaliul structural, articulația, contextul și efectul, spre a surprinde trăsături, a face descrieri și tipologii, oferind definiții consecvente. Cercetătorul conectat la perspectiva diacronică caută a cuprinde existența și devenirea organismelor şi proceselor la un nivel de complexitate și de profunzime cît mai rezonabil, spre a obține, precum creierul, înțelegerea realității. Urmărind filogeneza și ontogeneza, el caută să pătrundă relațiile și esența organismelor și proceselor, spre a dobîndi înțelegerea existenței și a devenirii.

Perspectiva sincronică poate servi înțelegerii detaliului structural, pus la microscop și cercetat static. Chiar și in situ, însă, analiza sincronică nu poate surprinde mișcarea, adică viața, ea fiind în mod inerent o fotografie a momentului. Observînd două momente succesive sau toate momentele unei etape, ea poate sesiza doar diferențele lor structurale și numai prin gîndire poate deduce mișcarea din acele diferențe.

\footnotetext{
${ }^{2}$ În esență aceasta este viața reală. Fiecare nivel al existenței poate fi privit sincronic, dar el există diacronic. O celulă, un țesut, un organ, un individ, o comunitate constituie materie vie și există, nici una dintre acestea, însă, nu contează, deci nu are existență reală, decît în măsură în care participă la o formă de existență superioară, la adaptarea, supraviețuirea, reproducerea și evoluția acesteia.

Datorită unor particularități date de conjuncția limbă-gîndire, oamenii se pot concepe atît de izolat încît apare tendinţa de a parazita comunitatea (profitînd, adică, de tendințele naturale ale grupului de a se agrega în fireasca modalitate a existenței diacronice). După apariția limbajului (la organismele vii) și dezvoltarea limbii (la ființa umană), omul a observat că acesta poate fi reificat și astfel poate acționa în lume. După folosirea limbii spre a obține-cu imense beneficii-coordonarea acțiunilor organismului social, s-a ajuns la exacerbarea și întrebuințarea nenaturală a capacităților acesteia de a induce comportamente, mai ales în funcție de dorințele și nevoile individului a cărui limbă căpătase o valoare mai mare.
} 
Analiza sincronică nu poate oferi concluzii de rang diacronic, deoarece alăturarea de momente statice nu poate genera curgere temporală, așa cum punerea laolaltă a celulelor excizate nu generează un țesut viu. Prin definiție, sincroniile nu se pot însuma, pentru că analiza sincronică smulge timpului obiectul și extirpă mişcarea, de unde limitele hotărîte și de netrecut ale sincroniei.

Perspectiva diacronică este mai puțin sensibilă la detalii structurale întrucît, fiind proprie contemplării existenței, procesualității și devenirii, ea nu poate pulveriza obiectul deoarece observă devenirea, urmărește mișcarea adaptativă şi evolutivă a structurilor, interrelațiile și funcționarea acestora, dincolo de care caută principii existențiale. Observarea și analiza unui prezent nu duce la înțelegerea reală a acestuia, ci doar la secvențializarea sa în gîndire. După încheierea acestui proces, însă, este imperios ca acel prezent să fie regîndit în dimensiunea sa vie, act care nu se poate petrece cu adevărat decît după schimbarea perspectivei. Abia astfel se poate afla și înțelege istoria devenirii realității care a ajuns să fie acel prezent ${ }^{3}$, abia o dată cu cunoașterea acestei evoluții se obțin premisele înțelegerii reale a oricărei realități.

Concentrată asupra unui obiect limitat prin decupare, analiza sincronică se încheie într-un punct, oricît de profund. Cugetînd asupra devenirii, analiza diacronică urmează mișcarea la nesfîrșit, în paralel căutînd principiile și legile. Caracterul procesual și dinamic-adaptativ al realităţii face ca aceasta să nu poată fi cuprinsă decît dintr-o perspectivă dinamic-integratoare.

Date fiind căile de structurare și de funcționare ale celor două tipuri de perspective și de analize, schimbarea de perspectivă necesită schimbarea instrumentelor și o implică pe cea a modalităților de interpretare și conceptualizare a datelor, ceea ce înseamnă și că cele două demersuri nu sînt compatibile şi realizabile simultan. Din toate aceste motive, încercarea de a obține rezultatele uneia cu instrumentele sau pe calea celeilalte este defectuoasă, iar înlocuirea analizei diacronice cu cea sincronică sau renunțarea la cea din urmă este pernicioasă și distructivă.

Cu toate că lucrurile nu pot fi observate decît individual și izolat, analiza sincronică nu este aptă să ofere înțelegerea unitară a lor, nici a proceselor realității, ea nefiind aptă să surprindă integritatea și procesualitatea. Ea nu poate ajunge la înțelegerea faptului că lupta organismului individual, aflat în competiție cu alte organisme, dă consistență sincronică unei ființe stăpînite de continuitatea diacronică. Așa cum aspectul și gustul unui fruct nu îndeamnă la apariția în conștiința umană a faptului că acestea nu sînt decît aparențele unor principii nutritive, ci, dimpotrivă, procură senzații și reflecții care vizează și susțin momentul, tot astfel cadrul aparent și eficient pe care îl oferă sincronia nu solicită căutarea esențelor pe care le exprimă.

Sincronia pare a fi o modalitate concretă de existență și manifestare a diacroniei, instrumentul și forma concretă a acesteia. În fapt, ea nu există aşa cum nu există secunda sau metrul, dar este o percepție ce facilitează acțiunea umană în cadrul ei existențial, și o convenție ce procură rezultate utile la nivelele existențiale imediate, rareori la unele profunde. Ca ajustare imaginată a realității la dimensiuni umane și ca ipoteză de lucru, sincronia este ușor de perceput—căci este fragmentară—și uşor de mînuit—căci este fragmentatoare-, ea îngăduind fixarea și manipularea porţiunilor de realitate, dar separate de organismul lor. Caracterul indispensabil al perspectivei și al metodei sincronice nu este consecința doar a coincidenței cu modalitățile primare de percepere și înțelegere a realităţii de către fiinţă, respectiv a maniabilității acesteia ${ }^{4}$, ci decurge totodată din complexitatea și dificultățile caracteristice perspectivei și metodei diacronice. Sincronia percepe ziua și noaptea, sistola și diastola, fluxul și refluxul, diacronia pricepe ciclul (circadian, cardiac, mareic), căci prima vede momentul în spațiu și surprinde existența, iar cealaltă înțelege întregul în timp și cuprinde existența ${ }^{5}$. De aceea, sincronistul este oricind gata să descrie, în vreme ce diacronistul

\footnotetext{
${ }^{3}$ În acest fel, metoda diacronică aduce corecția imperioasă că nici un prezent nu trebuie cercetat, interpretat și judecat din perspectiva prezentului analistului, aceasta fiind o eroare fundamentală din toate punctele de vedere.

${ }^{4}$ Perspectiva sincronică este modalitatea primară de luare la cunoștință și de înțelegere a lumii, analiza sincronică fiind instrumentul analitic pe care perspectiva și-l creează, spre a obține imagini clare, eficient-operaționale. Important este ca acest material să fie apoi furnizat ca atare tipului superior și deplin de analiză, blocarea în perspectiva sincronică semnificînd ignorarea legilor evoluției, cele pe baza cărora întreaga realitate există și funcționează.

${ }^{5}$ Structura este de descris, fiind un decupaj al realității, operat și analizat de către un observator static, în vreme ce mișcarea este de străbătut.
} 
își asumă caznele explicării, primul văzînd structura și aparența, celălalt pătrunzînd semnificația și esența.

\section{Diacronia ca modalitate a existenței}

Trăsăturile speciei, comune tuturor indivizilor acesteia, se transmit în mod implicit și pe cale naturală. Lor li se pot adăuga felurite particularități din rîndul celor cronicizate, pe care indivizii anteriori le-au dobîndit din interacțiunea intensă cu mediul, organismul trecîndu-le în rîndul atributelor sale. Schimbările amorsate și acutizate într-o sincronie, pot persista și supraviețui cronic, devenind și instaurînd o nouă stare, care impune noi condiții de supraviețuire, fapt ce solicită modificări structural-funcționale adaptate și coerente. Adaptările pot fi reținute de organismul (individual sau social) care astfel se edifică diacronic, achiziția fenotipică fiind un adaos sau o schimbare solicitată de adaptarea la o cantitate de schimbări ce-au generat o nouă stare calitativă.

Componenta informațională a sistemelor vii este deopotrivă supusă principiilor de economie și eficiență, capacităţile de stocare a informației fiind rezonabile în raport cu solicitările, iar dezvoltările permise de potențialul existent fiind suficiente adaptării la condițiile de viață. Fidelitatea informației transmise, moștenite și utilizate asigură stabilitatea (și implicit identitatea) indivizilor și speciilor. Una dintre căile asigurării acestei fidelități este redundanța care, firește, trebuie să cunoască cote rezonabile. Relevant, însă, este faptul că simplul procedeu—energofag—reprezintă un indice al caracterului imperios al continuităţii, adică al păstrării identității. O parte a acestei cerințe se rezolvă prin evoluția conținuturilor și a funcțiunilor (prin evoluția, înlocuirea și asignarea lor la aceeași formă).

După cum oamenii se diferenţiază pe baza propriei lor evoluții istorice, tot astfel și cuvintele diferă datorită ascendenței lor, a valorilor de întrebuințare, a conexiunilor (de familie lexicală, de cîmp semantic, sinonimice, antonimice, paronimice etc.) pe care viaţa lor le-a purtat. Sub acest aspect, alături de unul dintre rezultatele evoluției istorice de la nivelul formei și al sensului, polisemia (sincronică) -modalitate economică de organizare și de funcționare a limbii-, deosebit de relevantă este evoluția semantică (diacronică) prin schimbarea sau coexistența sensurilor (la interiorul unei limbi sau în urma unor contacte cu altele). Deși tipurile de situații sînt destul de numeroase, înfățișările efectelor oferind aparența varietății, mecanismul este acelaşi, efectele numite metonimie, metaforă, sinecdocă rezultînd din asocieri generate de procese cognitive și mentale.

a) Spre deosebire de un tip de polisemie, precum cel din rom. cap, care, de-a lungul vieții sale, prin asocieri și uzuri, a agregat istoric o serie de sensuri, vb. a socoti înglobează sensuri precum 'a număra, a calcula', apoi 'a considera, a lua în seamă', permise de notele comune ale sensului de bază cu celelalte, precum și chemate de posibilitatea substituirii cuvintelor corespunzătoare în anumite contexte, fapt care poate fi constatat și pentru alte limbi (fr. compter 'a număra' și 'a socoti', germ. zäblen 'a număra' și 'a considera'), adică cerut de gîndire și de habitudinile sociale, și permis de o limbă constituită istoric, în relație cu gîndirea și cu societatea, nu invers ${ }^{6}$.

b) În plan lingvistic, relația logică și semantică dintre notele de conținut ale noțiunilor capătă aparența sinonimiei, care este marcă sau indice al relației dintre cuvinte, nu neapărat în plan paradigmatic, dar în plan sintagmatic. Un astfel de tip poate fi ilustrat cu o serie cvasi-sinonimică precum: a încerca, a proba, a testa, a dovedi, verbe lipsite de relații genetice, dar cu sfere conținînd note comune sau coincidente, astfel încît uzul a valorificat această posibilitate de sinonimie contextuală, substituind formele conform cu adecvarea notelor la cerințele contextuale și de comunicare.

\footnotetext{
${ }^{6}$ Un cuvînt precum seamă (< magh. szám 'număr') apare în expresii precum: de-o seamă, a băgala lua în seamă, pe seama, a-și da seama, de bună seamă, a ține seama, o seamă de, larg cunoscute, utilizate și funcționale, dar lipsite în mintea vorbitorului de valoarea etimologică a vrom. $s(e)$ amă. Substantivul ar trebui să aibă valori precum: 'socoteală, cantitate, sumă, importanță, fel, rost', toate generate de posibilele relații ale acestora cu 'număr', sensul de bază al lui seamă. Cu toate acestea, chiar întrebat, vorbitorul obișnuit nu va ști sensul lui seamă, nici liber, nici în context, deși utilizează corect expresiile în discuție, lucru de înțeles, de altfel, deoarece cuvîntul (este greu de spus dacă seamă mai are toate atributele unui substantiv) apare doar în anumite structuri, neavînd independența unui cuvînt autosemantic obișnuit.
} 
c) Verbul a decima se referea la o modalitate de disciplinare folosită în armata romană, prin care o unitate de militari care încălcase în mod grav codurile militare și regulile de disciplină, suferea, prin tragere la sorți, o pierdere de efectiv de zece la sută. Astfel, o companie de dezertori, de pildă, era adusă în situația de a suferi, la nivelul unei părți a ei, aceeași soartă care ar fi putut-o aștepta, dacă ar fi înfruntat inamicul. Concepută pentru cei cruțați și păstrați în unitatea respectivă, corecția comportamentală viza înțelegerea faptului că, prin natura meseriei lor, militarii se confruntă cu moartea, lupta fiind oricum preferabilă; procentele aveau în vedere păstrarea unui număr cît mai mare de oameni, în condițiile unei execuții de amplă eficiență. Firește că, de-a lungul secolelor, această practică imaginată și aplicată într-un timp concret și particularizat de propria mentalitate și propriile practici, a fost privită şi considerată prin prismele diferitelor epoci succesive. În felul acesta și din acest motiv, termenul a ajuns să-şi schimbe semnificația și apoi sensul, în zilele noastre, a decima însemnînd 'a masacra, a ucide un (în) număr foarte mare, a extermina', sensul inițial fiind folosit doar specializat, devenind erudit ${ }^{7}$. Din alte cauze, dar în acelaşi chip procedural, lat. familia a generat forma rom. femeie 'familie', care apoi a evoluat abandonînd sensul etimologic și păstrînd sensul care se referea doar la una dintre notele de conținut, 'soție"s.

d) Cadranul solar indica inițial o formă rectangulară, iar schimbarea acestei forme cu una circulară nu a dus la ajustarea cuvîntului, așa cum subst. soldat 'cel care este remunerat cu moneda numită sold' nu a devenit *bănat, iar marfă (< magh. marha 'vită) a ajuns să nu mai aibă nici o legătură cu trocul sau plata în vite, dar a rămas să se refere la un „concept economic”.

e) Multe evoluții semantice încep cu modificări în direcția simplificării prin pierderea de nuanțe (uneori centrale, deseori subtile, rare în uz, particularizate diastratic), prin echivalarea cu un sinonim parţial, înlocuit apoi cu termenul nou. Nucleul acestui tip îl constituie cazul în care forma împrumutată (din altă limba sau strat social) este încărcată cu sensul preponderent al formei existente, aceasta din urmă fiind ulterior marginalizată, eliminată sau forțată să-şi caute alte uzuri, contexte și, eventual, nuanțe și valori ${ }^{9}$.

Exemplele de mai sus se referă la situații în care: a) o trăsătură (nu neapărat fundamentală, reprezentativă, ci doar evidentă, cumva frapantă) ajunge să domine conținutul conceptual al cuvîntului, să înglobeze note ale unor concepte corelate semantic și să determine în consecință corelațiile și contextele semantice ale termenului; b) datorită relațiilor semantice dintre unele sensuri, cuvinte diferite pot intra în relații sinonimice contextuale (uneori sub influența altei limbi), pînă la preluări (iniţial improprii) de contexte; c) se modifică perspectiva și concepția asupra realităţii desemnate; d) se modifică realitatea; e) apar simplificări în gîndire, activate asupra limbii mai ales prin expandarea bruscă și nejustificată de nevoi a sferei utilizatorilor cuvîntului. Caracterul economic al limbii (sub forma polisemiei, eventual sub aparențe subtile, şi în sensul tendinței de a economisi materialul prin reciclare), se manifestă prin reziliența structurilor și perisabilitatea conținuturilor, cu disponibilitatea de păstrare și refolosire a formelor, în contextul în care planul conținutului afectiv, ideatic etc. este supus dinamicii gîndirii și societății.

În general, din cauze de ordin economic, structurile sînt mult mai rezistente decît conţinuturile și funcțiunile, acesta fiind un principiu universal. Se pare că efortul înlocuirii acestora nu este rentabil decît arareori, tendința mergînd către nuanțare, modificare, înlocuirea conținuturilor și funcțiunilor, ajustarea sau înlocuirea structurilor fiind soluții extreme. Lucrul acesta poate fi observat în limbă, în evoluția anatomo-fiziologică a materiei vii, precum și în plan culturalspiritual, peste tot renunţîndu-se foarte greu la forme, indiferent de dinamica funcțiunilor și conținuturilor.

Calea predilectă și curentă de a denumi realitatea pare a fi constituit-o dintotdeauna metafora. Deși comportamentele vorbitorilor sint dependente de mărimea comunităților, de configurația

\footnotetext{
${ }^{7}$ Pentru complexitatea unor astfel de evoluții, a se vedea Gafton (2014a).

${ }^{8}$ Pentru un caz concret de gramaticalizare și de evoluție a nuanțelor vezi Gafton (2011).

${ }^{9}$ Pentru astfel de situații a se vedea Gafton (2014b)
} 
sinstratică a acestora și de istoricul social-mentalitar, în general, calea de denominație prin metaforă este eficientă—datorită transparenței și sugestivității—și la îndemînă—datorită celerității prin care, folosind analogia și intuiția realității, limba aduce necunoscutul în sfera cunoscutului. Metafora reflectă stadiul cunoașterii (adesea pe al percepției asupra căreia s-a reflectat cu cunoștințe și instrumente insuficiente și inadecvate). Chiar cînd reușesc aproape perfect să transmită intuiții-calea cunoașterii raționale și redate printr-o expresie lingvistică nuanțată fiind mult mai solicitantă pentru gîndire și mai anevoioasă pentru limbă—, prin ponderea lor metaforele indică o modalitate de comunicare ce reflectă adevărul că, în fapt, rațiunea nu este un atribut înnăscut, în vreme ce simţirea este, comunicarea lingvistică elaborată nefiind un dat, ci o cucerire care se păstrează prin efort constant. Se observă că în firea ființei stă reacția la mediu și la nevoi, conștiința de sine şi voința astfel orientate fiind capabile să activeze doar sporadic comunicarea prin efort rațional și conștient orientat ${ }^{10}$. Sub acest aspect, este semnificativ faptul că, în limbajele specializate-precum în cel științific, și nu doar la nivelul componentei sale vulgarizatoare-, metafora are rolul de a activa reflexele receptorului prin analogia cu conținuturi cunoscute, în acest scop folosind chiar și uzuri deliberat și explicit expresive.

S-ar crede că, în momentul în care chestiunile la care se referă sînt cel puțin la fel de lămurite în gîndire pe cît de lămuriți sînt termenii care poartă respectivele cunoștințe, știința ajunge să folosească o terminologie neutră, și că, pînă la a ajunge în acel punct, limbajul urmează căutările gîndirii (cale mai adecvată și mai eficientă pentru a sugera intuițiile asupra realităţii). În realitate, limba nu renunță prea ușor la formele pe care și le-a creat, proporția dintre renunțarea la unii termeni, cu preluarea altora și golirea metaforelor de componenta imaginativ-figurată, este mult mai echilibrată decît pare. De regulă, atunci cînd metafora pălește, moare sau este copleșită și infirmată de realitate, cuvîntul rămîne să dăinuiscă ca instrument și vehicul de comunicare. Mai mult, chiar cînd se apelează la prima soluție, termenii preluați sînt tot niște foste metafore, eliberate de imaginea plastică. Cazul care duce procesul către ultimele consecințe este gramaticalizarea prin desemantizare și decategorizare-favorizate de uzul intens al formelor în contexte fixe ${ }^{11}$. În plan biologic este relevantă relativ mica deosebire morfologică dintre membrele anterioare ale vertebratelor, de acum sau comparate cu cele ale altor ere geologice, și uriașa deosebire dintre capacitățile și funcțiunile membrelor anterioare ale unui strămoș al omului şi finele posibilităţi de întrebuințare ale membrelor superioare ale omului contemporan. În planurile social și cultural-spiritual, unde structurile funcționează aproape exclusiv pe bază de rituri și ceremonii, apare aceeași evoluție diferențiată la nivel de formă și de conținut: formele tind a fi păstrate, conținuturile sînt determinate de prefacerile realității ${ }^{12}$.

În același chip, balastul genetic ${ }^{13}$ (în special cel datorat mutațiilor și substituției) este semnul unei anumite zăbave în eliminarea genelor devenite inutile, o nesincronizare prudentă, ceva mai lentă decît rata încorporării achizițiilor. Deși o astfel de povară poate fi mare, rolul ei este important întrucît pe seama eficienței poate amplifica valențele adaptative și trăsăturile identitare; în subsidiar, oferă modelul și tiparul ratei de evoluție naturală, în condițiile unui mediu care poate da tonul multor schimbări și poate apoi reveni oscilant și capricios, păstrarea identității și a stabilității aflîndu-se mai aproape de existență decît variabilitatea și schimbarea adaptativă ${ }^{14}$.

\footnotetext{
${ }^{10}$ Barierele sintactice și lexicale, de uz și de normă pe cale le pune limba decurg din capacitățile de materializare a gîndirii prin limbă, din felul în care s-a constituit treptat limba, din felul în care nevoile de cunoaștere și de comunicare au fost satisfăcute prin efortul comunității, mai mult simțitoare și vorbitoare, doar într-o măsură gînditoare.

${ }^{11}$ Pentru acest fenomen, în general, și pentru unele situații relevante pentru limba română, a se vedea Heine \& Kuteva (2002), Hopper \& Closs Traugott (2003), Popescu (2006), Milică (2010), Niculescu (2011), Ușurelu (2011).

${ }^{12}$ A se vedea, printre altele, Loisy (1920), Bell (1992, 1997), Turner (2008).

${ }^{13}$ Sintagma se referă exclusiv la secvențele de material genetic răspunzătoare de structuri și funcțiuni cîndva active, devenite inutile ca urmare a evoluțiilor mediului. $\mathrm{Nu}$ este vorba despre atavisme propriu-zise, aflate în potență și actualizate accidental, ci despre elemente neutilizate, dar neeliminate din genom.

${ }^{14}$ Stabilitatea este una dintre condițiile fundamentale ale identității. Continua punere în discuție a aspectelor limpezite,
} 
În planul identității mentalitar-culturale avem a face, iarăşi, cu o edificare treptată, prin adiții, achiziții, acomodări și adaptări, în cadrul comunitar și social, și la realitate. Identitatea unei civilizații în ansamblul ei nu este dată doar de componenta strict naturală, de canavaua materială din care se edifică o structură minimal-funcțională, ci și de adițiile ce decurg din natura intimă a țesăturii, din acomodările la mediul propriu, precum și din unele acomodări prin adiție și ajustare, generate de contactul cu alte civilizații. Pe măsura înaintării în timp, cantitatea de cunoaștere transmisă generaţiilor succesive ale unei civilizații este în creștere, proporțional nu cu rata ei de plus-cunoaștere, ci cu rata ei de sedimentare și de consolidare a achizițiilor validate (cele două necoincizînd nici măcar ideal—în esență, datorită lipsei de viziune diacronică a societăților, decurgînd din tendințele firești de sincronizare ${ }^{15}$ ).

Dacă trăsăturile prin care omul socoate a se diferenția de celelalte animale, și prin care își țese iluzia unicității (limba, gîndirea, empatia, calculul, uneltele, cultura etc.) rămîn discutabile-în ciuda permanentelor redefiniri care nu au alt rol decît de a servi la argumentarea tezei prezumate-, s-ar putea totuși avea în vedere un element în măsură să opereze și să arate o deosebire relevantă, însă dobîndită pe cale procesual-istorică, nu fundamentală ori dată prin procesul umanizării, între ființa umană și celelalte animale. În cadrul unei comunități restrînse și sub condiția fragilă a păstrării integrității diacronice a grupului, multe dintre animale, dotate fiind cu capacități de observare, memorare și analiză precum și cu forme relativ complexe și nuanţate ale facultății de comunicare, pot agrega informații și comportamente sub forma unei culturi şi pot transmite de la o generație la alta anumite cunoștințe de ordin practic și deprinderi vitale. Cum condiţia poate fi satisfăcută cu intermitențe, animalele o iau periodic de la capăt. Datorită anumitor tipuri de dezvoltări ale capacității de comunicare, ființa umană a putut permanentiza procesul de transmitere a acestor date de-a lungul generațiilor. Înaintea și la baza acestei consecințe—din care decurg altele care ar fi eronat să treacă drept fundamentale și de prim rang, în ciuda spectaculozității lor ele fiind doar derivate (posibilitatea de creare a unor rețele tot mai vaste, care să cuprindă și să înglobeze cunoștințele cît mai multor oameni, cu consecința apariției posibilității de comparare, analiză, ierarhizare și sintetizare a datelor întregii rețele, cu consecința apariției posibilității de creștere exponențială a complexului astfel obținut)—stă, în fapt, capacitatea dobîndită de a înmagazina cunoștințele în modalități și recipiente superioare celor date de memoria unui individ sau a unei comunități. De aceea, epocile de regres urmează perioadelor în care omenirea (și-)a ignorat zestrea cognitivă sau a interpretat-o și folosit-o în mod și la nivel superficial.

Pentru ca întregul proces să funcționeze, pentru ca societatea să fie ferită de erorile de replicare (adică de erorile de „lectură a instrucțiunilor”, de interpretare a acestora și de construcție pe baza lor), de cele ale punerii în act a produsului și de cele de concepție a unor noi produse, este necesar ca acea civilizație să se afle în posesia deplină nu numai a produselor nodale, ci a întregului organism care a generat acele rezultate. Singura cale ce ferește de aceste erori este cea care oferă posibilitatea și capacitatea de a pătrunde cognitiv și cogitaţional, de a înțelege ansamblul întregului organism epistemic și gnotic acelei civilizații.

continua zăbavă în a epuiza idei de efect dar veștede, continua demitizare a aspectelor vremelnic puse la adăpost ca material de lucru pentru generații mai norocoase sub aspect metodologic și mai înțelepte, continua forjare a unor instrumente necerute de nivelul de dezvoltare al cunoașterii și de necesitățile extinderii edificiului, continua problematizare, mai cu seamă în planul superficial al sincroniei, sînt acte de disoluție a identităţii și de subminare a energiilor organismului.

Pe de altă parte, o construcție coerentă, sănătoasă și viabilă are nevoie de ajustări, cu reconsiderări din perspectiva sistemicității structurii, a funcționării eficiente a sistemului, în relație cu mediul și cu dinamica realității. În mod normal, acest lucru se petrece de la sine, nu pe baza unui program ideologic, întrucît oricît de mici sau de mari ar fi, organismele sînt cibernetice precum Universul care le-a generat. Intervenția conștiinței poate induce în eroare, deoarece aceasta subminează constant ceea ce este natural și favorizează nejustificat ceea ce este făcut în virtutea unei finalități orientate ideologic.

${ }^{15}$ Tendințele acestea sînt firești datorită forței naturale conținute de tendințele către minimum de efort, conjuncte cu cele care duc la îndeplinirea mai degrabă a nevoilor proxime și intermediare, decît a celor „ultime” și „finale”, adică este mai lesne și la îndemînă de vizat ceea ce este beneficial în mod vizibil și imediat, decît ceea ce ar putea folosi într-un viitor incert, este mai tentantă satisfacerea unei nevoi producătoare de plăcere, decît obținerea rezultatului real pe care împlinirea aceleia îl generează. 
Nevoile înțelegerii întregului-imperioase în situaţii specifice—pot solicita coborîrea la nivel de detaliu, spre a înțelege contextul unui aparat, al unui organ, al unui țesut, al unei celule, spre a coborî apoi la nivelul detaliului componentei, spre a înțelege anatomia, fiziologia și dinamica detaliului devenit organism, totul spre a reveni în cele din urmă, cu toate datele, la nivelul întregului, prin care toate există. Aceasta este și calea care ajută la evitarea erorilor de înțelegere, interpretare și acțiune petrecute în etapele evolutive precedente ale societății, ferind de reluarea erorilor și de dogmatizare.

Dată fiind continuitatea proceselor din Univers, existența este esențialmente și prin definiție diacronică și devenindă, repaosul și starea fiind echivalente cu inexistența.

Sincronia este o ipoteză teoretică de lucru, o metodă de abordare a viului, un moment în care se presupune că repaosul îngăduie observația a ceea ce este viu. Avînd în vedere dimensiunile parametrilor la care funcționează ființa umană, precum și însușirile unor realități precum societatea și limba-care, ca orice organism, sînt în sincronie și devin în diacronie -, utilitatea analizei sincronice este o realitate. Ca observație descriptivă amănunțită, ea poate servi cunoașterii proprietăților materialului, a modalităţilor sale de structurare în sine, spre a estima posibilitățile sale de a se supune îmbinării şi de a se ajusta la cerințele întregului, astfel încît, structural agregat, materialul și partea să-și asume rolurile în chipul cel mai eficient, în vederea participării la funcțiunea întregului. Mult mai dificil de operat, urmărirea parcursului diacronic nu doar procură înțelegerea structurării, constituirii și funcționării limbii, gîndirii, societății, lumii materiale, și nu este doar o sinteză totalizatoare, ci permite urmărirea și înțelegerea proceselor ce guvernează existența și evoluția unui organism viu.

\section{Concluzii}

Oricît timp ar putea măsura în urma ei, o comunitate nu dobîndește conștiința clară a diacroniei în mod reflex, ci reflectiv. Ea se dezvoltă într-un mediu, între anumiți parametri, cunoaște felurite interacțiuni formatoare, capătă o anumită organicitate structurală care-i aduce o oarecare coerență funcțională. Participînd la mediu ajunge să-l determine într-o oarecare măsură și îşi poate fixa anumite tipare de mişcare, chiar evolutive. Toate acestea îi pot asigura supraviețuirea, poate continuitatea, dar nu evoluția istorică.

Prin natura alcătuirii și funcționării aminoacizilor de la baza realităţii nici un şir de generații nu se poate plasa în descendența altui șir ignorînd efectele existenței, rezultatele sau produsele șirului anterior ori pe cele ale propriului șir, și nu poate întemeia un șir dacă desconsideră esența șirului. Nici chiar bazîndu-se pe sintezele succesive care elimină verigi mai mult sau mai puțin asimilate, generațiile nu pot—fără a suporta consecințe anulante-ignora șirul. Eliminarea treptelor pe temeiul imperfecțiunii acestora și reținerea doar a punctelor nodale contravine însuși modului în care se petrece procesul de transmitere a genelor, de construcție a organismelor prin răspuns la stimuli, de dezvoltare și evoluție. Este un tip de acțiune sincronică autoanulant, întrucît din diacronie se elimină „sincronii”.

Eliberat de iluzia sincroniei familiare și înconjurătoare, observînd retrospectiv calea de pînă la el, omul poate înţelege organicitatea şi integralitatea realităţii, cercetînd-o prospectiv. Ajunge acolo prin asumarea poziţiei celulare din cadrul unui organism milenar care, în cadrul interacțiunilor cu mediul, și-a ajustat structurile și funcțiunile. Abia pe calea acestui proces dobîndește deplinătate ființa umană edificată istoric, reflectînd totodată natura diacronică și dialectica oricărei entități existente, semnalînd necesitatea vitală a asumării conștiente, depline și continui a naturii sale fundamentale și esențiale. Neînțelegerea acestui adevăr duce la reluarea sisifică a oricărui travaliu, la zăbava sau la graba rătăcitoare, orice încercare de negare a caracterului istoric și procesual structurii și de exacerbare a funcționalităţii sincronice, nefiind decît o rupere a relației decalate dintre structură și funcție. 


\section{Bibliografie}

Bell, C. (1992). Ritual Theory, Ritual Practice, Oxford University Press.

Bell, C. (1997). Ritual: Perspectives and Dimensions, Oxford University Press.

Gafton, Al. (2011). Donc, în „Language and Literature - European Landmarks of Identity”, 8, p. 15.

Gafton, Al. (2014a). Avatarii evolutive ale conceptului 'a educa' în textele vechi românești, în „Dacoromania”, XIX (1), p. 53-67.

Gafton, Al. (2014b). Social dynamics and the linguistic norm, în „Diversité et identité culturelle en Europe”, XI (2), p. 7-24.

Heine, B. \& Kuteva, T. (2002). World Lexicon of Grammaticalization, Cambridge University Press, CrossRef.

Hopper, P.J. \& Closs Traugott, E. (2003). Grammaticalization, Cambridge University Press, CrossRef.

Loisy, A. (1920). Essai historique sur le sacrifice, E. Nourry, Paris.

Milică, I. (2010). Grammaticalisation et expressivité, în „Revue roumaine de linguistique”, LV (3), p. 301-312.

Niculescu, D. (2011). The Grammaticalization of the Future Tense Forms in 16th Century Romanian, in „Revue roumaine de linguistique", LVI (4), p. 421-440.

Popescu, I. (2006). Timp și limbaj: introducere în lingvistica lui Gustave Guillaume, Institutul European, Iași.

Turner, V. (2008). The Ritual Process: Structure and Anti-Structure, Aldine Transaction Press, New Brunswick.

Ușurelu, C. (2011). La grammaticalisation des opérateurs factitifs en roumain, în „Revue roumaine de linguistique”, LVI (2), p. 159-166. 